\title{
PROSPECTS FOR DEVELOPMENT \\ OF MEDIUM-TERM BUDGET PLANNING IN UKRAINE
}

\section{Yaroslav Berezhnyi ${ }^{1}$ \\ Nataliia Miedviedkova ${ }^{2}$}

DOI: https://doi.org/10.30525/978-9934-588-15-0-24

Abstract. The research goal is to deepen the theoretical and methodological aspects of medium-term budget planning and substantiate practical recommendations for its development in Ukraine. To achieve the research goal, the following tasks were defined:

- to summarize theoretical approaches for determining the essence of medium-term budget planning;

- to explore the mechanism for applying medium-term budget planning;

- to consider the components of medium-term budget planning, such as: the relationship between medium-term planning and the budget process, the level of detail in the structure of tax revenues and government spending, format of planning, medium-term budget goals, budget indicators, fiscal policy goals, fiscal rules, participatory budgeting;

- to analyze the foreign experience in applying the components of medium-term budget planning;

- to substantiate practical recommendations for development of medium-term budget planning in Ukraine.

The object of the article is medium-term budget planning.

The subject of the article is a combination of theoretical and practical aspects of forming and implementing medium-term budget planning.

Research methods. To achieve the goal of the article, the general scientific and special methods were used. Using the dialectical method of cognition, theoretical aspects of medium-term budget planning were substantiated. In order to determine the components of medium-term budget planning, a systematic approach was used. To process statistical data,

\footnotetext{
${ }^{1} \mathrm{PhD}$ in Public Administration, Chief Consultant,

National Institute for Strategic Studies, Ukraine

${ }^{2} \mathrm{PhD}$ in Economics, Assistant of Department of Finance,

Taras Shevchenko National University of Kyiv, Ukraine
} 
study their changes over time and establish the nature of the relationships between them - statistical and analytical methods were used. To characterize the components of medium-term budget planning - method of grouping, method of generalizing characteristics, tabular and graphical methods, the comparison method were used.

Currently, the budget planning system in Ukraine is imperfect, which poses a threat to the growth of the state budget deficit and public debt, and also worsens the efficiency of the use of funds. Therefore, medium-term budget planning arises as an important tool for bodies that form fiscal policies, since it makes it possible to extend the period for assessing the consequences of decisions in the field of fiscal policy more than one budget period.

It was found that currently medium-term budget planning, as the main mechanism for harmonizing the budgeting, programming and forecasting of socio-economic development, has a number of positive consequences for public administration, such as: it increases the responsibility of public authorities for the consequences of current management decisions; maintains proper fiscal discipline; ensures the establishment of a stable fiscal balance and debt burden on the state budget of the country. The transition to medium-term planning in Ukraine will provide a strategic approach to the allocation of resources, as well as improve forecasting of budget expenditures, which will help ensure costs for the implementation of medium-term government planning.

The study of the individual components of medium-term budget planning (such as: the relationship between medium-term planning and the budget process, the level of detail in the structure of tax revenues and government spending, format of planning, medium-term budget goals, budget indicators, fiscal policy goals, fiscal rules, participatory budgeting) allowed to identify shortcomings and offer practical recommendations for their elimination and further development of medium-term budget planning in Ukraine.

\section{Introduction}

Formulation of the problem. The constant development of the global economy and the public finance system encourages the search for new high-quality models of public finance management along with forecasting the needs of societies and the development of appropriate public policies. Government programs tend to have a medium-term effect, which should be taken into account in subsequent years. Consequently, social progress 
points to a certain limitation of annual budgeting models and the need to use medium-term mechanisms of budgeting, forecasting and programming of socio-economic development.

The medium-term budget planning mechanism is one of the key tools for fiscal policy formation. It makes it possible to extend the period for assessing the consequences of decisions of more than one budget period. Medium-term planning of the state budget is a process where resources are determined for the medium term and the use of these resources is determined in accordance with the priorities identified by the government.

The flexibility of this mechanism has contributed to the emergence and development of a new instrument for obtaining financial stability at the local level - the practice of participatory budgeting at the local level. The practice has received various forms and models of application, so the question of the mutual addition and joint application of the medium-term budget planning mechanism at the national level and participatory budgeting at the local level, as well as other components of medium-term budget planning (in particular, medium-term budget goals and fiscal rules) remain open.

The identification of previously unresolved parts of the general problem. In general, the first multi-year budgets were introduced in the 1960-1970s of the XX century even during the period of the Keynesian doctrine of active state intervention in the economy that was objectively accompanied by the expansion of the public sector. In those years, multi-year budgets were an instrument for allocating funds in future budgets for the implementation of certain programs and projects.

Multi-year budgets were the driving force behind cost increases, as government departments viewed plans as a guarantee of future increases in financial resources. However, over time, it became impossible to maintain a constant pace of expansion of the public sector, and plans often created expectations, did not materialize and ruined the stability of state finances.

Therefore, governments reoriented the planning framework of multiyear budgets into forecasts, and the budgets themselves turned from a means of expanding costs into a means of limiting and reducing them. Signs of such a transformation are the transition from making plans in physical units to value predictions.

Currently, budgeting is subject to the rule - the available resources are intended to implement existing budget priorities, and there are no reserves 
for new ones [1]. Consequently, since the mid 90s of the XX century there was a transition to a medium-term budgetary mechanism in the formation of state financial and macroeconomic policies.

With the abandonment of central planning and curtailing government spending, participatory budgeting practices arose as a mechanism for stimulating local development without a direct dependence on national development priorities and, accordingly, going beyond the narrow framework of financing local development from the national level.

However, the independent functioning of these financial mechanisms for planning public spending at different levels (national and local) contributes to a number of contradictions among public resource managers, caused by the lack of common target aggregates.

Therefore, the goal of our study is to deepen the theoretical and methodological aspects of medium-term budget planning and substantiate practical recommendations for its development in Ukraine.

\section{The results of the study}

In most countries of the world, the state budget is drawn up for one year. However, new tendencies of scientifically and quantitatively substantiated prediction of the prospects for economic development and the consequences of current financial policies for the future come into force. In the Member States of the European Union under the Stability and Convergence Programs (1996), a mandatory three-year forecasting in the field of fiscal policy and budgeting was gradually introduced, which made it possible to increase the effectiveness of monitoring the implementation of stabilization programs. In addition, with the deployment of the economic recession of 2008-2012, the intensive implementation of the expanded stability and convergence program (Stability and convergence programs, 2009) has begun. As well as preventive measures, the European Commission has developed recommendations for establishing fiscal rules and their application for the medium term [2]. As a result, governments develop medium-term and longterm estimates and forecasts of the fiscal state. The process has acquired the designation medium term budgetary framework (medium-term budget mechanism). In practice of the International Monetary Fund, it received the name of medium-term budget planning (hereinafter - the MTBP) [3]. Its application has a noticeable effect for the EU, the fiscal positions of most 
states that have implemented medium-term planning at the legislative level have significantly improved and made it mandatory.

The success of the experience gained by European countries along with the practice of implementing strategic planning in other countries made the MTBP the main mechanism for harmonizing budgeting processes and forecasting socio-economic development in the world. Moreover, it expands the potential for using strategic planning and management in public administration. The main components of MTBP are shown in Figure 1.

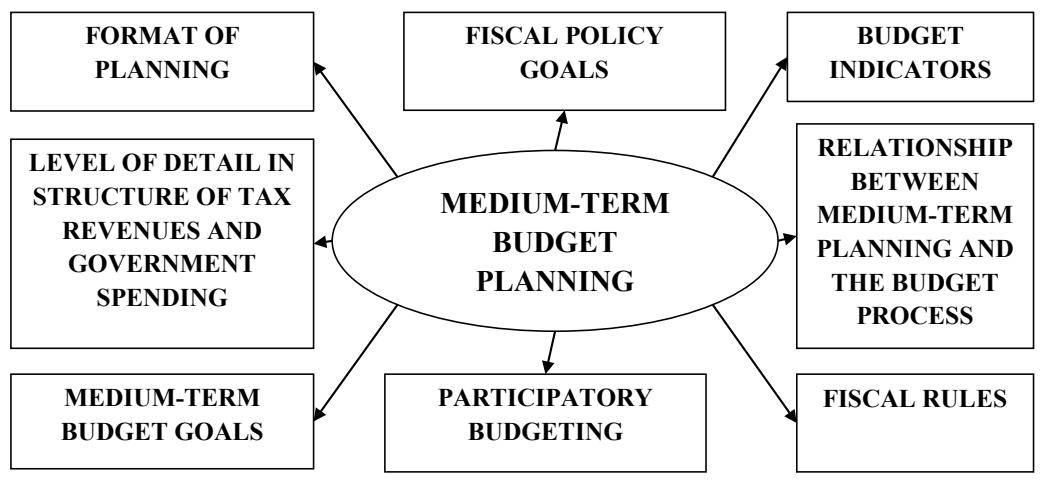

Figure 1. The components of medium-term budget planning

Source: compiled by the authors

Therefore, there is a constant increase in the value of the relationship between medium-term planning and the budget process. By this time, in many countries medium-term planning was for reference only. In particular, only half of the EU countries have mechanisms to adjust the current state of the budget in accordance with the medium-term plan. The presence of such mechanisms, according to the recommendations of the European Commission, is a sign of a quality MTBP. The adjustment mechanisms in the EU countries have different implementation methods, however, they have a similar principle of action; the deviations from the plan in the current period creates obligations to compensate for this deviation in the future. The compensation mechanism can be different: the manager who exceeded the plan of expenses in the current period may be obliged to reduce the expenses of the future period by the amount of the excess, or this amount 
can be distributed over the next several planning periods. An important role is also played by the system for processing the excess of the current period: unused funds can either be added to the budget of specific fund managers in subsequent periods or sent to a centralized reserve and redistributed in favor of more priority spending areas [4].

The functioning of the MTBP in the EU countries is quite indicative. The most important planning element is the selection of an object of goal-setting, that is, a specific indicator that the government considers to be the key and in the medium term defines the goal of developing public finances in the form of a specific numerical value of this indicator (state budget deficit, share of public debt, GDP growth rate, expenses and country income). The vast majority of countries practice medium-term deficit and spending control. It is also quite common practice to set limits and restrictions on the volume of public debt. Revenue targeting is relatively rare, because most countries see medium-term planning as the goal of ensuring fiscal balance, and therefore the goal of fiscal policy is medium-term deficit restrictions. At the same time, revenues are a kind of free variable and act as a basis for viewing the established cost restrictions [5].

The most common practice in the EU is three-year planning. On the one hand, this period makes it possible to adhere to the foreseeable future dynamics of macroeconomic indicators, and on the other hand, it provides fiscal policy makers with adequate medium-term planning tools. In particular, from 23 EU countries in 17 countries, plans are drawn up for a three-year period; in Austria, Estonia, Finland - for a four-year period, in the Netherlands - for the period of stay in power of the coalition government (4 years); in Ireland and the UK - excellent planning timelines have been set for different targets; in Denmark - the current plan covers five years. At the same time, the revision of budget policy objectives in the medium term is usually not allowed (an exception for the practice of Denmark, Finland and France).

At the same time, medium-term budget planning in the EU member states has not received final legal forms. Many countries continue to regard plans and forecasts as a rough, rough estimate, and therefore do not consider it necessary to adjust the current budget according to these rough estimates. In addition, most countries have introduced a model MTBP only at the central budget level or at the level of national government. This indicates the insufficient penetration of medium-term planning into the European budget system, 
since local budgets remain outside this mechanism, although it is a key element of fiscal discipline. Only three countries (Sweden, Ireland, and Slovenia) carry out full-fledged medium-term planning [6]. Forecasting accuracy is constantly growing, so confidence in medium-term plans is also increasing.

In order to ensure that all fiscal policy goals are consistent with the latest economic development data and legislative changes, a flexible format of planning is used, providing for the possibility of annual revision. The unchanged format of planning for the most important goals implies the inability to change them over a certain period. The most often unchanged in the medium term goals are government spending (in real or nominal terms), which cannot be reviewed from year to year unless extraordinary events occur (a sharp decline in economic growth, a change of government). This format of planning makes it possible to avoid viewing the target indicators of the budget expenditures in case of higher than expected indicators of economic growth. Also, this format of planning implies a close relationship between the MTBP and the annual budget adoption process.

A rolling and periodic format of planning is also distinguished. A periodic format of planning covers a certain period of time, that is, if some extraordinary events do not occur, it implies a lack of planning until the planning period ends. Period of planning is usually determined by law. But the rolling format of planning provides for the annual addition of new annual indicators to the existing plan.

Most EU countries use a flexible rolling planning format. Only in some countries, in particular in the Netherlands, Finland, Sweden, and to a lesser extent in the UK and Denmark, expenditure targets are not being revised. In addition, a periodic format of planning is used in the UK, Denmark and the Netherlands. Basically, a rolling format of planning is combined with a flexible format, since the process of annually adding a new year, you can view the set medium-term goals. Although there are cases of establishing a combination of rolling and fixed planning formats (Sweden) [7].

An important sign of good medium-term budget planning is the level of detail in the structure of tax revenues and government spending, which strengthens stability and confidence in the medium-term budget goals of market participants. The detailed distribution of expenditures by departmental and program classification provides the heads of sectoral ministries and departments with information on the amounts of funds provided for the implementation of 
planned activities and also helps to find ways of saving on expenses that have lower priority. The preparation of detailed plans should be carried out with the direct participation of line ministries, local authorities, social insurance funds, which are better aware of the specifics of the items of expenditures. In most EU countries, medium-term plans cover a limited set of budget indicators: budget balance, debt, income and expenses. Only a few countries, in particular Sweden, Slovenia and the United Kingdom have detailed medium-term plans.

Many countries use medium-term budget planning, which ensures the development of a sustainable approach to public financial management. Medium-term budget goals can be reflected in various legislative and regulatory acts: can be approved at the legislative level (Slovenia and Sweden); can be indicated in the coalition agreement of the parties included in the government coalition (Netherlands and Austria); can be given in the appendix to the budget law for the current year (France and Poland) [8].

It is worth noting that in Latvia, in addition to the Law on Budget and Finance Management, the Law on Fiscal Discipline is used to develop medium-term budget planning. Thus, medium-term budget planning and financial management in Latvia are carried out in accordance with the principles of fiscal policy established by the Law on Fiscal Discipline, ensuring transparency and compliance with fiscal policy [9].

Most countries use a model based on an annual definition of medium-term goals. It is stipulated that if the goals of the fiscal year are retained for the next year, it is possible to continue such goals without approving the new edition (Latvia). If budgetary goals are not formed on an ongoing basis (Finland, the Netherlands and the UK), a strictly defined period of time is used to use existing ones [10].

Foreign experience indicates that the process of adjusting budget goals may vary. In particular, budget goals: do not change depending on specific circumstances (Finland and Sweden) can be changed in accordance with changes in parameters defined by national regulations (Austria and Latvia); can be changed in cases provided by national legislation (Hungary and Poland); can be changed at the discretion of the government without a public explanation (Slovenia and Slovakia); and with a public explanation (Czech Republic and Lithuania); can be increased in the case that the amount of additional costs is expected and necessary, and the level of inflation is also taken into account (Netherlands and Denmark) [11]. 
At the same time, currently in Ukraine the budget planning system is imperfect, which poses a threat to the growth of the state budget deficit and public debt, and also worsens the efficiency of the use of funds. Therefore, medium-term budget planning arises as an important tool for bodies that form fiscal policies, since it makes it possible to extend the period for assessing the consequences of decisions in the field of fiscal policy more than one budget period. The MTBP is compiled on the basis of macroeconomic forecasts, and therefore it is possible to determine in the medium term that the government will have enough funds to finance all adopted programs. Therefore, the bodies that determ the fiscal policy carry out the calculation of the main budget indicators (budget balance and debt, expenses, income, and their components) for the medium term at the level of the general public administration sector.

MTBP has its advantages, which are as follows. Firstly, it increases the transparency of fiscal policy in the medium term, informing market participants about the possible state of public finances in future. Information on planned activities in the field of fiscal policy provides them with the opportunity to more correctly determine their own goals. It helps to ensure that governments pursue a balanced fiscal policy, reducing the threat of the impact of new decisions on the growth of the budget deficit. Secondly, the MTBP allows you to extend the planning term of fiscal policy and determine the impact of new decisions in the field of fiscal policy in the medium term, and not just in the current budget period. Under such conditions, it is much more difficult for governments to hide or underestimate the shortcomings of their urgent decisions to balance public finances in the medium term. In addition, the very fact of determining and disclosing the goals of the budget policy is already an incentive for the government to comply with them. In such circumstances, it is much more difficult to postpone or ignore changes in the fiscal policy which are necessary to ensure the stability of public finances in the medium term.

Medium-term budget planning also makes it possible to effectively solve the problem of a constant lack of funds to finance all activities and programs, lobbyed by various interest groups in society, which in fact is the main reason for the further increase in budget deficits and public debt. Having jointly determined the maximum amount of expenditures that the government can carry out without worsening the state of public finances, 
the participants in the budget process are focusing their efforts on redistributing these resources, rather than justifying the need to allocate additional funding for a particular program.

Also, medium-term budget planning is one of the important tools for improving the process of fiscal policy formation. Its absence increases the risk that budget expenditures will be redistributed as a result of decisions on the allocation of additional funds, for which it is necessary to review previous or current decisions. In the event that previous decisions were made by political opponents, viewing the funding programs may have political implications. Therefore, medium-term budget planning makes it possible to strengthen the quality and stability of the decision-making process. In addition, the MTBP can have a positive impact on the achievement of structural reforms related, for example, to the redistribution of powers between sub-sectors of the general government sector. These reforms usually last for several years, so medium-term budget planning allows participants in this process and market participants to see the benefits and results of such changes. This facilitates the perception and implementation of complex reforms [7].

The first and most important condition for achieving the planned budget indicators is the quality of macroeconomic forecasts. A reassessment of GDP growth rates in the medium term may lead to the planning of overestimated government spending. In the future, when ministries and departments expect the previously determined volume of appropriations, it is very difficult to revise costs downward in the case of lower than expected GDP growth rates. However, the problem is to predict GDP growth rates in 3-4 years, which did not deviate from the actual indicators. A possible way to solve this problem is to plan budget indicators, based on pessimistic forecasts regarding economic growth, or laying additional reserves, which provided an opportunity to increase costs and / or reduce costs in case of lower than expected economic growth indicators. In order to avoid the possible use of incorrect macroeconomic forecasts with the aim to increase costs in the medium term, in several countries of the European Union (for example, Belgium, the Netherlands and Austria), macroeconomic forecasts are independent from the government.

The second condition for the effectiveness of the MTBP is the realism of fiscal policy objectives. There is a high likelihood of using MTBP for opportunistic purposes. Governments can avoid or delay the adoption of politically 
complex fiscal consolidation measures by exaggerating the prospects for improving the state of public finances in the medium term, and promising a sharp reduction in deficits and debt. In order to avoid corresponding risks, it is necessary to ensure the realism of fiscal policy objectives.

Firstly, medium-term goals should be coordinated with all political forces that influence the implementation of fiscal policy. The active role of parliament in the process of setting budget goals is one of the indicators of such coordination. It is also necessary to ensure the presence of coordinated actions of bodies and institutions that influence the implementation of fiscal policy. In some countries, medium-term goals are considered as indicative, and there are no political or legislative obligations to comply with them. But in other countries (Slovenia, Sweden) target fiscal indicators are approved at the legislative level. In other countries (Netherlands, Austria), medium-term budget goals are defined in the coalition agreement of the parties included in the government coalition. In Finland, medium-term budget goals are set for the cadet period of the new government. In France and Poland, the main medium-term budget indicators are given in the appendix to the current year budget law.

Secondly, medium-term budget planning should have a direct impact on fiscal policy. Therefore, it is imperative that the MTBP has a close relationship with the process of adopting the annual budget, starting the last of the discussion and implementation of the goals identified in the MTBP. In case of deviations from the plans, it is necessary to argue and explain the reason for their appearance. Only in a few EU countries the government publishes information on the deviation of actual indicators from the targets planned for the medium term. In Spain, in particular, the government assesses the risks of deviating from plans and notifies the competent authorities. If a deviation is recorded, the government is developing a three-year action plan to restore the situation. In Slovakia, the Ministry of Finance regularly publishes reports on the compliance of actual indicators with the planned ones. In the event of deviations from the plan, the government proposes remedial measures.

Thirdly, the essence of the MTBP forecasts (plans) should be obvious and transparent. It is necessary to clearly determine whether the MTBP parameters are forecast or target, that is, the budget indicators that are expected to be achieved, provide for the absence of a targeted change in fiscal policy, it is necessary to take certain measures in order to implement them. In the case of 
setting targets for fiscal policy, it is necessary to show the difference between the targets and the state of public finances in the absence of changes [7].

An integral part of medium-term planning is a system of fiscal rules and restrictions. As a rule, the basis for the medium-term plan is precisely these limitations. Cost planning is carried out on the basis of established rules that are implemented to stabilize public finances and prevent excessive deficit growth [11], in particular:

- fiscal rule should be legally approved and generally binding. Practice shows that only a strict legislative framework under a fiscal rule can ensure its implementation;

- perennial nature. Fiscal rules should be effectively integrated into the medium-term planning system. Any fiscal rule should be designed in such a way which takes into account the medium-term effect of the current implementation;

- effective accounting system. It is necessary to effectively monitor the state of public finances. A standardized monitoring system should work, which will provide an information base for further planning;

- protective mechanisms and sanctions. Each fiscal rule should be designed in such a way that its execution is protected. Protection is a set of actions provided in case of violation of this rule. The protective mechanism has two goals at the same time: to limit the negative impact of the violation and stop the activity that led to the violation. In the case of significant violations, sanctions were imposed on the direct violators of fiscal discipline;

- exceptions. An important element of any effective fiscal rule is the existence of exceptions when deviations from this rule are possible. This approach allows us to make the system more flexible and to exclude situations where the presence of a particular fiscal rule only reduces the effectiveness of the functioning of public finances. However, it is necessary to formulate the conditions for exceptions very specifically, and make exceptions for a small number of cases.

Specific fiscal rules are developed in countries in accordance with the conditions of their functioning, features of the budget system and the needs of the national economy. In addition, the European Commission defines the key elements that should be embodied in the medium-term planning system:

- The medium-term plan should cover all government spending, or at a minimum, central government spending and the social security sector. The 
planning period should be 3-4 years (including the current year). It is advisable to carry out planning with a deep granularity of expenditures by sector;

- cost limits. Practice shows that medium-term plans that set spending limits are most effective. At the same time, expenses should be limited both at the general level and at the level of managers of lower-level funds;

- adequate revenue forecasting. Revenues to the budgets of various levels are projected in accordance with the economic situation. The degree of detail of the forecast income should correspond to the degree of detail of expenses;

- analysis of deviations. All deviations from the plan should be carefully studied and explained. The causes of errors in the forecast, and the behavior of participants in the budget process, which led to deviations, should be studied;

- drawing up several scenarios of the macroeconomic situation. The forecast of macroeconomic indicators should consist of several scenarios in order to be able to apply various fiscal regulation tools if the situation develops according to one or another scenario;

- legislative linkage of medium-term planning to the budget. Current legislation regarding the budget process should include a mechanism for interacting with medium-term forecasts. This is necessary so that medium-term planning has little real impact on the budget process;

- effective monitoring and adjustment mechanisms. The macroeconomic situation has been carefully monitored. In the event of deviations from the plan, an action program must be foreseen in advance and must act as a reaction to these deviations [12].

As international experience shows, fiscal rules and regulations are introduced for various reasons, such as:

- ensuring macroeconomic stability (Japan);

- increasing confidence in the fiscal policy of the government (Canada);

- ensuring long-term sustainability of the Tax fiscal policy (New Zealand);

- minimizing negative external effects within the framework of a single monetary union or federation (EU countries).

Among the EU countries, various approaches are used to include fiscal norms of budget legislation. In particular, in Great Britain they are included in the Code of Financial Stability, and Fiscal Rules are even included in the Constitution in Germany. 
Currently, participatory budgeting is a form of participatory democracy at the local level, providing a systematic approach to attracting citizens to the budget decision-making process of a particular territorial community. Thanks to the participatory budgeting, citizens are given the right to decide where exactly to spend part of the public resources.

The participation of citizens in the budget allocation procedure is different, which is the subject of research by many scientists. National and foreign scientists analyze this process, identifying key principles that should be observed in the participatory budgeting process: decisions made by citizens are respected by local governments; the procedure of participatory budgeting is simple, transparent and understandable for most citizens; discussion should take place in the public forum - the selection of the projects should be the result not only of voting, but mainly debate; the process should favor the inclusion of citizens, supporting their ideas and activities; participatory budgeting has to be a repeated process; strategic, long-term thinking should dominate during the decision-making process; the amount of money should be high enough in order to have an impact on changes in the city area [13].

The participatory budgeting mechanism originated in Porto Alegre (Brazil) in 1989. And within a few years of its implementation, it contributed to the achievement of positive results, in particular, it reduced the level of corruption, significantly improved the quality of education and health and improved the city's sanitation and sanitation system.

And although in opinion of many scientists, the participatory budgeting model which was introduced in Porto Alegre, is considered as an ideal model, this model is not the only one used in the world. World practice provides for the use of other models, in particular: participation of organized interests; community funds at local and city level; the public/private negotiating table; proximity participation; consultation on public finances.

It is worth noting that these models differ in the following criteria: participants (citizens, trade unions, associations, non-governmental organizations, etc.); sphere of application (investment priorities, special projects); decision-making (discussion with detailed proposals and clarifying important issues / public meeting and questioning); source of funds (municipal budget and fund, independent for the municipal budget; funds of private entrepreneurs); implementation process (the participants implement the project themselves, and the local government introduces projects selected by citizens) [13]. 
The experience of Porto Alegre has been adopted by many countries in North America, Africa, Asia and Europe, expanding the network of citizens participating in the process of making decisions in the budgetary sphere together with local authorities. Since 2000 participatory budgeting has begun to be actively used in Europe (in particular, in Spain, Belgium, Italy, Germany, France, Portugal, Denmark, Switzerland, the Netherlands, Great Britain) [14]. And in the countries of Central and Eastern Europe (Bulgaria, Moldova, Poland, Romania), the first attempts to begin the process of participatory budgeting began only in 2010 .

Thus, participatory budgeting as a tool for deliberative democracy is becoming increasingly popular in Polish cities. The idea of implementing the first participation budget in Poland appeared in 2010. As part of the Sopot Development Initiative, an informal group that operates in the city of Sopot to implement the requirements of sustainable development and expand public participation [15]. In recent years, more and more municipalities in Poland have decided to introduce participatory budgeting. The advantages of their application in Poland are as follows: a wide range of projects that can participate on a competitive basis; better understanding of the needs of society; an impulse to create new social activities and public organizations; the guaranteed amount of money tends to increase over the next years.

At the same time, the Polish mechanism of participatory budgeting is not without certain drawbacks, such as: debates and other forms of discussion are organized quite rarely; often the procedure focuses on the competition of projects, rather than on the challenges and problems of local politics; inadequate criteria for checking the project (verification usually takes place without the participation of citizens); participatory budgeting procedures are usually proposed by the local government without additional meetings and consultations; the procedure rarely takes into account various types of territories and their ranking; participatory budgeting is interpreted as a political tool for improving the image of local politicians.

For the first time in Ukraine participatory budgeting was introduced in 2015 in three cities: Chernihiv, Cherkassy and Poltava. Areas of its application can be as follows: safety; roads and transportation; culture and tourism ecology; education; health care; social protection; sport; information technology; civil society; utilities, energy saving; public space. 
Currently, participatory budgeting as an instrument of direct democracy, already works in more than 70 cities in Ukraine. The leaders in terms of the participatory budgeting are Kiev, Kharkiv, Lviv and Dnieper.

Participatory budgeting in Ukraine was implemented with support from Ukrainian and international organizations, such as:

- PAUSI Foundation under the project «Participatory Budgeting Opportunities for Enhancing Public Activism and Establishing True Partnership with Authorities» (with the support of the Polish-Canadian Democracy Support Program);

- USAID which provides financial support for participation projects, while the «Institute budget and Social and Economic Research (IBSER) supports the implementation of projects;

- Ukrainian technological public organization SocialBoost, which in 2016 created an online platform «Public Project», which helps Ukrainian cities to automate the process of the participatory budgeting;

- Local Government Development Centres (LGDC) were opened with support of the EU-funded programme "Ukraine - Local Empowerment, Accountability and Development" (U-LEAD with Europe) and the Ministry for Regional Development, Construction, Housing and Communal Services of Ukraine (MinRegion);

- The Association of Ukrainian Cities (AUC) was founded in June 1992 with 35 member-municipalities. Nowadays, AUC is a non-governmental, non-profit, and non-partisan organization which unites 574 Ukrainian cities, districts, settlements and villages where more than $95 \%$ of Ukrainian urban population lives. AUC contributes to the conceptual, legislative, financial and practical aspects of local self-government development in Ukraine. AUC has its central office in Kyiv with 40 highly qualified specialists and the network of 24 regional offices of Ukraine.

Nowadays, the introduction of a participatory budgeting in Ukraine is at an initial stage. Risks and shortcomings that prevent its effective use are associated with the following:

- a limited amount of funding for one project threatens the possibility of its implementation;

- funds for the implementation of projects are allocated for the next year after the voting (during this period the project may lose its relevance); 
- the coordination of projects and voting for them last a long period of time (in some cases even up to 6 months);

- funds for the implementation of the project are not received by the initiators of the projects, but by the municipal services under city councils;

- in the case of «freezing» the project, it is difficult to restore the organization of the voting process for the continuation of this project and its win, as well as bringing the project to its logical conclusion.

\section{Conclusions}

Currently, the budget planning system in Ukraine is imperfect, which poses a threat to the growth of the state budget deficit and public debt, and also worsens the efficiency of the use of funds. Therefore, medium-term budget planning arises as an important tool for bodies that form fiscal policies, since it makes it possible to extend the period for assessing the consequences of decisions in the field of fiscal policy more than one budget period.

It was found that medium-term budget planning, as the current main mechanism for harmonizing the budgeting, programming and forecasting of socio-economic development, has a number of positive consequences for public administration, such as: it increases the responsibility of public authorities for the consequences of current management decisions; it maintains proper fiscal discipline; it ensures the establishment of a stable fiscal balance and debt burden on the state budget of the country. The transition to medium-term planning in Ukraine will provide a strategic approach to the allocation of resources, as well as improve forecasting of budget expenditures, which will help ensure costs for the implementation of medium-term government planning.

The study of the individual components of medium-term budget planning (the relationship between medium-term planning and the budget process, the level of detail in the structure of tax revenues and government spending, format of planning, medium-term budget goals, budget indicators, fiscal policy goals, fiscal rules, participatory budgeting) allowed to identify shortcomings and offer practical recommendations for their elimination and further development of medium-term budget planning in Ukraine.

We found out that an integral part of medium-term planning is a system of fiscal rules and restrictions. Key elements that should be embodied in the medium-term planning system are as follows: the medium-term plan should 
cover all government spending, or at least the costs of central government and the social security sector; cost limits; adequate revenue forecasting; deviation analysis; drawing up several scenarios of the macroeconomic situation; legislative linkage of medium-term planning to the budget; effective monitoring and adjustment mechanisms.

In order to effectively develop the participatory budgeting in Ukraine, it is important to take into account not only the shortcomings and risks that occur in our country, but also the experience of other countries involved in the development of the local financial system and the implementation of the participatory budgeting. The international practice of implementing participatory budgeting shows the importance of active actions of non-governmental organizations and other public associations, constant control by the public.

\section{References:}

1. Biudzhetna polityka ta biudzhetne planuvannia $\mathrm{v}$ umovakh prohnoznoi nevyznachenosti: rehionalnyi riven: nauk.-metod. rozrobka / avt. kol.: A.H. Akhlamov, O.V. Holynska. - K. : NADU, 2010. - S. 18.

2. Rekomendatsii shchodo formuvannia fiskalnykh pravyl u krainakh YeS. Availableat:http://ec.europa.eu/economy_finance/db_indicators/fiscal_governance/ documents/analysis_national_fiscal_frameworks_pfr_2010.pdf

3. Biudzhetna polityka ta biudzhetne planuvannia $\mathrm{v}$ umovakh prohnoznoi nevyznachenosti: rehionalnyi riven: nauk.-metod. rozrobka / avt. kol.: A.H. Akhlamov, O.V. Holynska. - K. : NADU, 2010. - S. 17.

4. Kozoriz A.V. Zarubizhnyi dosvid zdiisnennia serednostrokovoho biudzhetnoho planuvannia u konteksti mozhlyvostei yoho zastosuvannia v Ukraini. Available at: http://ecofin.org.ua /srednesrok_za/

5. Funktsionuvannia serednostrokovoho biudzhetnoho planuvannia u krainakh YeS. Available at: http://ec.europa.eu/economy_finance/db_indicators/fiscal_ governance/documents/mtbf_2009_final.xls

6. Serednostrokove biudzhetne planuvannia v krainakh YeS. Available at: http://ecofin.org.ua/med_term_bud_eu/

7. Medium-term budgetary frameworks in the EU Member States in 2006. Availableat:http://ec.europa.eu/economy_finance/db_indicators/fiscal_governance/ framework/index_en.htm

8. Serednostrokove biudzhetne planuvannia (mizhnarodnyi dosvid). Available at: http://euinfocenter.rada.gov.ua/uploads/documents/29131.pd

9. Medium Term Budget Planning. Available at: http://www.fm.gov.lv/en/s/ budget/medium_term_budget_planning

10. Mizhnarodnyi dosvid serednostrokovoho biudzhetnoho planuvannia: uroky dlia Ukrainy. Available at: https://feao.org.ua/wp-content/uploads/2017/06/FEAO_ Sered_budget_planning_A5_05_web-2.pdf 
11. Kozoriz A.V. Zarubizhnyi dosvid zdiisnennia serednostrokovoho biudzhetnoho planuvannia u konteksti mozhlyvostei yoho zastosuvannia v Ukraini. Available at: http://ecofin.org.ua /srednesrok_za/

12. Rekomendatsii shchodo formuvannia fiskalnykh pravyl u krainakh YeS. Available at: http://ec.europa.eu/economy_finance/db_indicators/fiscal_ governance/documents/analysis_national_fiscal_frameworks_pfr_2010.pdf

13. Adam Polko. Models of participatory budgeting - the case study of Polish city / Adam Polko // Journal of Economics \& Management. - 2015. № 19. - P. 34-44.

14. Perspektyvy zaprovadzhennia biudzhetu uchasti v Ukraini na osnovi zarubizhnoho dosvidu / O. Kyrylenko, I. Chaikovska // Visnyk Ternopilskoho natsionalnoho ekonomichnoho universytetu. - 2015. - Vyp. 2. - S. 86-100.

15. Ofitsiina internet-storinka Sopotskoi initsiatyvy rozvytku. Available at: http://www.sopockainicjatywa.org 